\title{
SiM
}

\section{The Evolving Role of Women as} Rangeland Educators and Researchers in Colleges and Universities and in the Society for Range Management

\author{
By Amy C. Ganguli and Karen L. Launchbaugh
}

\section{On the Ground}

- In the last 30 years, women have increased in SRM membership percentage, which appears to have paralleled the number of women hired into academic positions and women entering the discipline.

- Although the history of women as SRM members and rangeland educators is relatively short, the increase seems to reflect that of related disciplines.

- Gender demographic changes have increased diversity within the SRM and many academic institutions, enhancing what each offers.

- Disproportionately fewer women receiving recognition and advancing to leadership positions within SRM or higher ranks within academia may reflect opportunities for the range profession to address.

Keywords: change agents, range profession, retention, women in science.

E papel evolutivo de las mujeres como educadoras e investigadoras en materia de pastizales y tierras silvestres en colegios/universidades y en la Sociedad para el Manejo de Pastizales y Tierras Silvestres (SRM)

Perspectiva desde el campo:

- En los últimos 30 años, las mujeres han aumentado su porcentaje de membresías en la SRM, lo cual parece haber seguido un desarrollo paralelo al número de mujeres contratadas en puestos académicos y de mujeres que ingresan a la disciplina.

- Aunque la historia de las mujeres como miembros de la SRM y educadoras en materia de pastizales y tierras silvestres es relativamente breve, el incremento parece reflejar el de disciplinas relacionadas.

- Los cambios demográficos por género han incrementado la diversidad dentro de la SRM y muchas instituciones académicas, mejorando la oferta de cada una de éstas.

- El desproporcionadamente bajo número de mujeres que reciben reconocimiento y avanzan hasta puestos de liderazgo dentro de la SRM o los rangos superiores dentro de la academia podría reflejar oportunidades que deben ser abordadas por la profesión pastoril.

W omen play an increasingly pivotal role in rangeland research, management, and education as our profession adapts to an expanding diversity of rangeland values and stakeholder interests. Like other natural resource disciplines, rangeland ecology and management was historically dominated by men. Indeed, those who founded and built our profession were, with few exceptions, men. Over the last 30 years, women have joined our profession in increasing numbers, similar to patterns observed in other biological and agricultural disciplines. ${ }^{1,2}$ During this time, the rangeland profession has undergone considerable evolution to be more inclusive of contemporary issues facing rangelands, including a higher emphasis on resource conservation and multiple-use man- 
agement. This expansion of rangeland values and interests fostered a new and diverse group of people that included women pursuing rangeland degrees and careers.

Our objectives in this paper are to discuss the changing role of women in the Society for Range Management (SRM) and as rangeland educators and researchers at colleges and universities. We will highlight the specific role that greater participation of women plays in mentoring and preparing new professionals to face the modern challenges of rangeland management. Finally, we will suggest strategies for retaining and sustaining women in the range profession to advance rangeland management and ensure the relevance of our profession well into the future. Although we acknowledge the role women range professionals play within agencies, nongovernmental organizations, and private corporations, we do not address their evolving role due to sparse data.

\section{Women and SRM}

Women have been an integral part of SRM from its inception. Women initially played important roles in supporting their husbands' professional careers or worked with their spouses and family members to run ranches. These women first attended SRM meetings as spouses, forming a close-knit group that provided forums for social interactions during the annual SRM meetings. By the 1980s, women were increasingly attending SRM as professionals in the field. These women attended section and international meetings alone or brought male spouses, and by the 1990s they were also bringing children. The influx of women into SRM brought different life and professional experiences, different management and leadership styles, and different needs for professional development.

In response to the increasing number of women in the workforce, several professional women worked with the SRM leadership to establish a professional women's breakfast, which was held during the annual SRM meetings. The breakfast was open to all members and focused on issues that tended to affect professional women. Topics discussed included solutions to issues concerning childcare, work-schedule expectations, elder care, and how to expand opportunities for women in our profession.

Over time, the breakfast morphed into a Professional Issues luncheon or breakfast with a broader focus beyond those affecting women in our profession and was discontinued in 2009. A group known as the "wild women of range" began holding informal social events at the annual meetings in 2000 to promote networking and to provide women an opportunity to share their passion for the range discipline. At this time there are no formal committees in place or programs within SRM to address gender or cultural diversity issues.

Membership in SRM appears substantially more balanced today than in previous decades. There are noticeably more women attending and participating in meetings, serving in leadership positions, and participating in the undergraduate and graduate student competitions than in previous years. Women are often the winners of student contests and are the leaders of student chapters of the Society. Although there have been many indications that the gender demographics within SRM are substantially different today, data are lacking because the SRM does not presently track demographic data that includes gender and ethnicity.

\section{Women as Change Agents in SRM and Academia}

Gaining the title of "trendsetter" or "trailblazer" is recognition of the great achievement of being the first in an endeavor. Such was the case just a few decades ago when women began seeking doctoral degrees in rangeland ecology and secured positions in research and teaching at universities. Women have been active within range academics for about 30 years (Table 1 ). ${ }^{3}$ The first female academic range educator was Edith Allen, who began instructing at Utah State University in 1983 (Table 1). ${ }^{3}$ Linda Hardesty was soon to follow in 1985 at Washington State University. In 1986, Barbara Allen-Diaz and Patricia Johnson joined University of California, Berkeley, and South Dakota State University, respectively, and Lynn Huntsinger joined the faculty at the University of California, Berkeley, in 1989. During this first decade of women contributing to range academic departments, eight women were hired (Table 1). The next decade added an additional nine women in range academic positions, with two people leaving, for a total of 15 women. In the following decade, 12 women were added as range educators with one person leaving bringing the last decade's total number of female academics to 26 .

An increasing number of women seeking range degrees and the occurrence of the first women range professionals occurred in the 1970s and ' 80 s when women were gaining initial prominence in many disciplines in agriculture and science throughout the country. For women entering colleges and universities, it was certainly reassuring to see other women as professors in their classes and as rangeland professionals. It was evidence the door was open to women who wanted to practice rangeland science and management and that the rangeland profession was open and accepting of women.

Today, there are more women professors and researchers than at any time in the past (Table 1 ). These academic women serve as role models to women students pursuing rangeland degrees, showing that there are no insurmountable obstacles for women entering our profession. Having women in the halls of academia is also important on a more personal level for women and male students. Every woman range professor has stories of students who confided in them and asked for advice on personal topics that they would have been unlikely to discuss with a male professor or supervisor.

The growing number of women professors in university classrooms advances diversity in the rangeland profession beyond serving as role models. These women serve as models of leadership and authority for both male and female students. As students graduate and join the profession they will have more experience with diverse approaches to teaching and leadership 
styles in land management agencies and organizations. In addition, women have helped their male colleagues and administrators adjust to a changing workplace and in some instances address emerging issues such as diversity in the workplace.

\section{Issues Facing Women in SRM and Academia}

There are many things to celebrate when evaluating the progress women have made in the rangeland profession over the last 30 years. Although we lack demographic data to illustrate this, the number of women entering the range profession at all ranks appears to have increased similar to trends observed in other fields. ${ }^{1,4}$ In addition, many women in science-related fields suggest that cases of overt sexism and gender bias have decreased. ${ }^{3}$ Despite this progress, research on women in science professions continues to illustrate disparity in salaries, promotion rates, and productivity. ${ }^{3,5}$ Furthermore, women continue to be more likely to leave the field, ${ }^{4}$ especially in academic arenas, contributing to the phenomenon known as "the leaky pipeline."

\section{Are Woman Recognized for Achievement in the Range Profession?}

Forty years ago, members of the range community may have asked if we are ready for women in the range discipline. This question quickly became irrelevant because of several pioneering women who became productive members within the range discipline with support and encouragement from men and other women in the field. What appears to be an appropriate question for the range community to consider now is this: Are we ready to acknowledge the role women have had within the range profession and are we willing to support women in positions of leadership?

Honor awards have been given during SRM annual meetings since 1967 (Table 2). Of the four highest awards given during these meetings (i.e., Frederic Renner, Chapline Land Stewardship, Chapline Research, and Sustained Lifetime Achievement), all of the 136 recipients have been men. The SRM Fellow award, which recognizes exceptional service to the SRM has been given to 192 individuals (four women). The Outstanding Achievement award has been given to 319 individuals (16 women) and the Outstanding Young Professional award has been given to 47 individuals (14 women). The Range Science Education Council Undergraduate teaching awards, also presented during SRM annual meetings, have been given to 32 individuals (two women).

Each year SRM holds elections to select two individuals to serve 3-year terms as directors, and one individual to serve as president (a 3 -year term with the first 2 years being in vice presidential roles). Since the Society's inception in 1948, there have been 12 women elected to director positions and two of these women have gone on to serve in vice presidential and presidential roles, Angela Williams served from 2003 to 2005 and Jennifer Pluhar is serving from 2012 to 2014 (Table 3). With regard to range academic leadership positions, three women have advanced into administrative roles in addition to their research and teaching. Barbara Allen-
Diaz was the chair of the Dept of Environmental Science, Policy and Management and is currently serving as the vice president for the University of California, Division of Agriculture and Natural Resources. Also at the University of California, Berkeley, Lynn Huntsinger is serving as the chair of the Division of Society and Environment. At the University of Idaho, Karen Launchbaugh is serving as the director of the Rangeland Center and was formerly their department chair.

Considering that the history of women as active participants in SRM and as range academics is relatively short, (e.g., approximately 30 years) we expect there to be a lag in areas like honor awards and election leadership positions. However, our review of women elected to leadership positions (Table 3), women receiving honor recognition within SRM (Table 2), and women who are in academic leadership positions illustrate that this lag is still present and that women appear to be underrepresented in these areas especially when considering present gender demographics within the range profession. There are likely many factors contributing to this disparity, including subconscious perceptions resulting in women not being nominated (see section on subconscious bias below).

Does the Range Profession Have a Leaky Pipeline? When looking at careers in academia as a linear progression of undergraduate and graduate education to postdoctoral fellow and assistant, associate, and full professor positions the pipeline analogy is often used. When pipelines are leaky, individuals leave at various stages, a phenomenon that has plagued women in a wide variety of academic science disciplines. ${ }^{1,2}$ Although we lack consistent data specific to the range profession, ${ }^{6}$ things have been improving for the last 40 years at all levels within academia; ${ }^{1,2,6}$ that is, the numbers of women as students and individuals employed at the various levels have been increasing. In fact, many agricultural and biological science disciplines have undergraduate enrollment that is greater than $50 \%$ women. $^{2}$ Enrollment in graduate programs in agricultural and biological sciences remains high; however, the pipeline is especially leaky when looking at the transition from doctoral programs to academic careers. ${ }^{1,2}$

\section{Are Academic Careers Appealing to Women?}

There are likely many reasons contributing to the leaks in the academic pipeline for women from the doctoral stage to assistant professor positions. An extensive assessment of gender differences at critical career transitions in the sciences conducted by the National Research Council ${ }^{7}$ found that the number of women applicants for faculty positions was lower than the number of women doctoral students in the sciences. However, this assessment revealed that women applying for faculty positions were more likely to receive interviews and to be offered positions. ${ }^{7}$ Does this mean that academic careers are simply less appealing to women? The current academic model may be less appealing to some women in science when issues of high stress and heavy workloads relative to pay and the desire to have families are considered. ${ }^{8,9}$ However, these 
Table 1. Women involved with rangeland education at North American colleges and universities for greater than one academic semester

\begin{tabular}{|c|c|c|}
\hline Name*t & Institution & Years \\
\hline Edith Allen & Utah State University & $1983-1988$ \\
\hline Linda Hardesty & Washington State University & 1985-present \\
\hline Barbara Allen-Diaz & University of California & 1986-present \\
\hline Patricia Johnson & South Dakota State University & 1986-present \\
\hline Lynn Huntsinger & University of California & 1989-present \\
\hline Carolyn Grygiel & North Dakota State University & 1990-2012 \\
\hline \multirow[t]{2}{*}{ Karen Launchbaugh } & Texas Tech University & $1992-1996$ \\
\hline & University of Idaho & 1996-present \\
\hline Debora Peters (formerly Coffin) & Colorado State University & 1992-1998 \\
\hline Ann Hild & University of Wyoming & 1996-present \\
\hline Susan Edinger Marshall & Humboldt State University & 1996-present \\
\hline Loreen Allphin & Brigham Young University & 1996-present \\
\hline Georgia Younglove & Chadran State College & 1998 \\
\hline \multirow[t]{2}{*}{ Maria Fernandez-Gimenez } & University of Arizona & $1999-2003$ \\
\hline & Colorado State University & 2003-present \\
\hline \multirow[t]{2}{*}{ Karen Hickman } & Forth Hayes State & 1999-2004 \\
\hline & Oklahoma State University & 2004-present \\
\hline Laurie Abbott & New Mexico State University & 2000-present \\
\hline Wendy Gardner & Thompson Rivers University & 2000-present \\
\hline \multirow[t]{2}{*}{ Tamzen Stringham } & Oregon State University & $2001-2008$ \\
\hline & University of Nevada-Reno & 2008-present \\
\hline Lan Xu & South Dakota State University & 2004-present \\
\hline \multirow[t]{2}{*}{ Beth Newingham } & University of Nevada-Las Vegas & $2004-2008$ \\
\hline & University of Idaho & 2008-present \\
\hline
\end{tabular}


Table 1. Continued

\begin{tabular}{|c|c|c|}
\hline Name $^{\star \dagger}$ & Institution & Years \\
\hline Jen Obrigewitch & Dickinson State University & 2005-present \\
\hline \multirow[t]{2}{*}{ Sandra Rideout-Hanzak } & Texas Tech University & $2005-2010$ \\
\hline & Texas A\&M University-Kingsville & 2010-present \\
\hline Elizabeth Leger & University of Nevada-Reno & 2006-present \\
\hline Eva Strand & University of Idaho & 2007-present \\
\hline Gail Wilson & Oklahoma State University & 2007-present \\
\hline Jordge LaFantasie & Fort Hays State University & 2008-present \\
\hline \multirow[t]{2}{*}{ Amy Ganguli } & North Dakota State University & 2009-2012 \\
\hline & New Mexico State University & 2012-present \\
\hline Kari Veblen & Utah State University & 2011-present \\
\hline Laura Perkins & South Dakota State University & 2012-present \\
\hline Robin Verble Pearson & Texas Tech University & 2012-present \\
\hline \multicolumn{3}{|c|}{$\begin{array}{l}\text { *Information prior to } 1996 \text { was derived from the Bedell report }{ }^{3} \text { and has been supplemented with data collected by the authors } \\
\text { † Does not include academic extension personnel and may omit some range-related faculty who hold positions in ecology or } \\
\text { other disciplines. }\end{array}$} \\
\hline
\end{tabular}

issues alone do not seem to explain the underrepresentation of women in academic science positions, especially when disciplines such as medicine share a lot of the same stressful attributes but do not have the same level of underrepresentation. ${ }^{8}$

\section{Is There a Subconscious Gender Bias?}

Research aimed at identifying gender-based discrimination in hiring practices revealed gender discrimination against women does indeed exist. ${ }^{5}$ But, what is really interesting is that the gender bias in this study was observed for both male and female employers. Specifically, a fictitious female applicant for a biology lab manager position was offered the position less frequently, was offered lower pay, and was provided fewer opportunities for professional development than an identical fictitious male applicant. ${ }^{5}$ Even though these applicants were identical in everything except for gender, these decisions were made because the female candidate was considered less competent than the male applicant. ${ }^{5}$ The researchers attributed these alarming findings to "pervasive cultural stereotypes," which fueled a subconscious bias or an unintentional prejudice against women. ${ }^{5}$

\section{A Way Forward}

Early pioneering women in the range profession are quick to discuss the influences that both men and women range professionals had and continue to have in their careers. ${ }^{6}$ In writing this paper we hope to create awareness about issues that we believe still need to be addressed. We need to ensure that SRM is committed to achieving a culture of inclusiveness and diversity and we need to work on developing strategies to address those. Below we highlight several issues and offer potential solutions.

At this time, SRM has no formal structure to address gender or cultural diversity issues. Information on these demographics within SRM would help the range profession address issues of retention within the professional society, something that is known to be an issue within academia in the agricultural, biological, and ecological sciences. ${ }^{2,4,8}$ One potential solution is to consider developing a task force to specifically work with SRM to identify the current demographic traits of our profession and use this information to identify the need for additional actions or programs. This would include working with SRM staff to improve our membership data to address demographic ques- 
Table 2. Summary of Society for Range Management honor award recipients by gender from the year each award was initiated

\begin{tabular}{|c|c|c|c|}
\hline \multirow{2}{*}{ SRM Award* } & \multirow{2}{*}{ Years } & \multicolumn{2}{|c|}{ Recipients } \\
\hline & & Female & Male \\
\hline Frederic Renner & $1972-2013$ & 0 & 44 \\
\hline Chapline Land Stewardship & $1987-2013$ & 0 & 28 \\
\hline Chapline Research & $1987-2013$ & 0 & 26 \\
\hline Sustained Lifetime Achievement & $1992-2013$ & 0 & 38 \\
\hline Fellow & $1977-2013$ & 4 & 188 \\
\hline Outstanding Achievement & $1967-2013$ & 16 & 303 \\
\hline Outstanding Young Professional & $1988-2013$ & 14 & 33 \\
\hline Undergraduate Teaching (RSEC) $)^{+}$ & $1988-2013$ & 2 & 30 \\
\hline \multicolumn{4}{|c|}{$\begin{array}{l}\text { *A complete description of all the SRM awards, including award recipients can be found at www.rangelands.org/awards/. } \\
\text { †A description of the Range Science Education Council Undergraduate Teaching awards, including award recipients can be } \\
\text { found at http://www.rangelands.org/RSEC/RSEC.htm. } \\
\text { RSEC indicates Range Science Education Council. }\end{array}$} \\
\hline
\end{tabular}

tions such as gender, age, and ethnicity. Professional organizations such as the Ecological Society of America have been addressing issues like this for 20 years through committees such as "Women and Minorities in Ecology" and could provide a model for our approach. We believe that SRM members are committed to the sustainability of the range profession and as demonstrated in the past, would likely participate in formal and informal opportunities to ensure this sustainability. Having a better picture of who we are as a profession gives us the opportunities to identify where we are doing well and where we should seek resources to improve our recruitment and retention efforts.

Since both men and women exhibit bias against women ${ }^{6}$ and this bias is largely subconscious we believe it needs to addressed rather than denied. Like most problems, the first step in overcoming gender bias is admitting that it exists. It is often much easier for people to self-identify instances where gender bias is affecting their ability to objectively evaluate a given situation, so it is important for individuals to be aware of their own biases. Because both women and men are guilty of gender bias, it is important to create awareness through open, nonjudgmental discussions about how to overcome these issues. The importance of establishing an environment where these issues can be discussed in a nonjudgmental way is critical for men and women to work together to address their conscious and subconscious bias regarding gender based assessments. ${ }^{10}$ A simple, but important, step toward overcoming our subconscious gender bias is for each of us to "consciously" nominate deserving women when the call for awards and professional recognition comes from SRM or the organizations and agencies for which we work.

Perhaps the most valuable rangeland resources we manage are people. Declining membership and poor retention are issues that SRM has faced in the past and continues to battle. Efforts targeting the initial stages of the leaky pipeline within SRM include new professionals who have just completed their schooling and have entered into the workforce. This group of young professionals within SRM, has been working with SRM leadership to promote the Young Professionals Conclave while addressing issues to improve the retention of this demographic.

\section{An Emerging Future}

Women in the range profession have come a long way since the time when it was extremely rare to encounter a female range conservationist employed by a government agency or a female rangeland professor in college. ${ }^{6}$ However, there are many opportunities to strengthen the rangeland profession and build a more diverse workforce. An improved picture of SRM's demographic, as well as the contemporary needs of range professionals, will facilitate the development of formal and informal programs to improve retention and recruit pro- 
Table 3. Women who have served in elected leadership positions within the Society for Range Management since its inception in 1948

\begin{tabular}{|c|c|c|}
\hline Name & Years & $\begin{array}{l}\text { Position } \\
\text { held }\end{array}$ \\
\hline Marilyn Samuel & 1987-1989 & Director \\
\hline Barbara Allen-Diaz & 1991-1993 & Director \\
\hline Linda Hardesty & 1994-1996 & Director \\
\hline Meg Smith & 1995-1997 & Director \\
\hline Angela Williams & 1997-1999 & Director \\
\hline Carolyn Hull Seig & 1998-2000 & Director \\
\hline Angela Williams & $2003-2005^{*}$ & President \\
\hline Karen Launchbaugh & 2005-2007 & Director \\
\hline Ann Hild & $2006-2008$ & Director \\
\hline Jennifer Pluhar & $2008-2010$ & Director \\
\hline Sandra Wyman & 2009-2011 & Director \\
\hline Stephanie Larson & 2010-2012 & Director \\
\hline Misty Hays & $2011-2013$ & Director \\
\hline Jennifer Pluhar & $2012-2014^{+}$ & President \\
\hline \multicolumn{3}{|c|}{$\begin{array}{l}\text { *Presidential term was in } 2005 . \\
\text { †Presidential term will be in } 2014 \text {. }\end{array}$} \\
\hline
\end{tabular}

fessionals to underrepresented aspects of the range profession's demographic relative to trends in closely related science disciplines and society in general.

The challenges rangeland professionals face to maintain and improve rangeland resources are immense. A diverse and capable workforce will be needed to address these challenges. Indeed, women are an important component of the rangeland profession now and will continue to be well into the future.

\section{Acknowledgments}

We appreciate our men and women colleagues and friends who have shared their ideas and experiences with us over the years and who served as sounding boards for our manuscript. Barbara Allen-Diaz provided valuable insight that strengthened the quality of this manuscript. We also appreciate Vicky Trujillo's assistance with historical information requests about the Society for Range Management. Presentations at the 2013 SRM symposium Women as Change Agents on the World's Rangelands, in Oklahoma City, formed the basis of this article.

\section{References}

1. Luckenbill-Edds, L. 2002. The educational pipeline for women in biology: no longer leaking? Bioscience 52:513-521.

2. Shaw, A. K., and D. E. Stanton. 2012. Leaks in the pipeline: separating demographic inertia from ongoing gender differences in academia. Proceedings of the Royal Society of Biological Sciences 279:3736-3741.

3. Bedell, T. E. 1999. The educational history of range management in North America. Denver, CO, USA: Society for Range Management. 159 p.

4. McGuire, K. L., R. B. Primack, and E. C. Losos. 2012. Dramatic improvements and persistent challenges for women ecologists. Bioscience 62:189-196.

5. Moss-Racusin, C. A., J. F. Dovidio, V. L. Brescoll, M. J. Graham, and J. Handelsman. 2012. Science faculty's subtle gender bias favors male students. Proceedings of the National Academy of Science 109:16474-16479.

6. Youtie, B. A. 1984. Woman: a growing range resource. Rangelands 6:23-24.

7. National Research Council. 2010. Gender differences at critical transitions in the careers of science, engineering, and mathematics faculty. Washington, DC, USA: The National Academies Press. 366 p.

8. Adamo, S. A. 2013. Attrition of women in the biological sciences: workload, motherhood, and other explanations revisited. Bioscience 63:43-48.

9. Ceci, S. J., and W. M. Williams. 2011. Understanding current cause of women's underrepresentation in science. Proceedings of the National Academy of Science.

10. Raymond, J. 2013. Most of us are biased. Nature 495:33-34.

Authors are Assistant Professor, Dept of Animal and Range Science, New Mexico State University, Las Cruces, NM 88003,USA, ganguli@nmsu.edu (Ganguli); and Rangeland Center Director and Professor, Dept of Forest, Rangeland and Fire Sciences, University of Idaho, Moscow, ID 83844, USA (Launchbaugh).

Rangelands 35(6):15-21

doi: 10.2111/RANGELANDS-D-13-00037.1

(C) 2013 The Society for Range Management 